\title{
Pawel Chmielnicki: Activity rules of economic man in society as the source of legal norm
}

\author{
Warszawa, 2010
}

\author{
Jürgen G. Backhaus
}

Published online: 28 January 2011

(C) Springer Science+Business Media, LLC 2011

Pawel Chmielnicki is a professor at the Jan Rochanovski Humanistic and Natural Science University at Warsaw who tries to merge institutional economics with macroeconomics on the basis of Polish data. Chmielnicki concludes that "human needs do not change; they are only differentiated and are only enhanced by manner in which they engage in activities in order to satisfy these needs" (p. 284).

He continues: "People are stimulated to examine the objectives and methods of the activity in the context of defining their position in the community" (ibidem).

"The possibility of satisfying needs by using the patterns that are protected by the community (...) is one of the most important goods acquired due to being a member of the community" (ibidem). "The normative set comprises a set of information (about) (...) the payoffs and the costs related to achieving the assumed result" (p. 285).

And "the process of creating the sources of law is subject of quantitative changes that are of the nature of long term trends" (ibidem).

While the backbone of law and economics is microeconomics basically price theory in the Posnerian tradition here-for a theorist in the Marxist tradition- the link to macroeconomics is more congenial. In this aspect the work is rather unique.

The book is largely based on Polish sources, but the authors are aware of public choice and lax and economics, citing Buchanan, Coase, Hayek, Landes and Posner, von Mises, Olson, Schumpeter and Tullock but also Galbraith and Veblen.

\footnotetext{
J. G. Backhaus ( $₫)$

University of Erfurt, Erfurt, Germany

e-mail: juergen.backhaus@uni-erfurt.de
} 